\title{
Risk Mitigation of Tobacco Supply Chain: Business Process Model
}

\author{
Silvana Maulidah* \\ Department of Agricultural Economics, Faculty of Agriculture, Brawijaya University, Veteran St., \\ Malang 65145, Indonesia
}

Received: 7 November 2020; Revised: 19 November 2020; Accepted: 23 November 2020

\begin{abstract}
Tobacco and its industrial products are a massive business in international trade. As a potential agroindustry, the tobacco products industry requires a supply of raw materials that must meet quantity, quality and continuity. The complexity of the tobacco supply chain network and the rapidly changing world business dynamics, pose risks in its business processes. An optimal supply chain risk mitigation or risk management strategy needs for the resilience of the tobacco supply chain in the disruption. The purpose of this study is to analyze the level of risk priority and also to formulate a risk mitigation strategy for the tobacco supply chain through a business process model approach. The method of analysis is the Delphy method and the House of Risk (HoR). The business process adopted from the SCOR (Supply Chain Operations Reference) model. The results showed: the priority level of tobacco supply chain risk is: economic uncertainty, tobacco is not available at the farm level, the location of tobacco raw materials is far from production activities, product prices have risen due to customs and product demand has increased sharply. Supply chain risk of mitigation strategies includes: increasing the flow of information in the tobacco supply chain, managing the stock/supply of tobacco raw materials and processed products, evaluating distributor selection, establishing partnerships with tobacco farmers, implementing a marketing mix strategy (product, price, location, promotion), increasing coordination with relevant governments, and management of information systems and technology.
\end{abstract}

Keywords: risk mitigation; supply chain; tobacco

\section{How to Cite:}

Maulidah, S. (2020). Risk Mitigation of Tobacco Supply Chain: Business Process Model. HABITAT, 31(3), 149-160. https://doi.org/10.21776/ub.habitat.2020.031.3.18

\section{Introduction}

Tobacco (Nicotiana sp.) is one of Indonesia's essential plantation commodities, which contributes significantly to the country's foreign exchange. According to the DirectorGeneral of Customs and Excise at the Ministry of Finance (2019), the most considerable revenue from customs duties comes from the tobacco industry in the form of cigarettes with IDR 153 Trillion or around $95.8 \%$ of total state excise revenue in 2018. Tobacco production in Indonesia is in the sixth position in the list of tobacco producers. Largest in the world with an average production of $1.91 \%$ (United States Department of Agriculture, 2018). East Java Province is one of the main producing areas for tobacco commodities, with a total production in 2019 of 85,053 tonnes, accounting for $46.39 \%$ of national tobacco production (Directorate General

*Correspondence Author.

E-mail: silvana.fp@ub.ac.id of Plantations, Ministry of Agriculture, 2020).

The tobacco products industry is a potential business that requires a large supply of raw tobacco materials. The amount of tobacco raw materials needed does not entirely come from domestic production and must import. This problem appears because the amount of domestic production is still in the range of 180-190 thousand tons/year and is not sufficient for the national need of 330 thousand tons/year.

Due to the high competition in the tobacco product industry, this agroindustry requires a study regarding its competitive advantage. The tobacco products industry needs to have competing priorities, including the cost of leadership, quality, responsiveness, and flexibility, to achieve this advantage. For this reason, the agroindustry needs to optimize its entire supply chain network or, in other words, to integrate supply chain or supply chain management. Tobacco supply chains have complicated and complex supply chain flows; industrial products require special handling and involve many actors or entities. Supply chain 
management is planning, designing, and controlling the flow of goods, information, and money along the supply chain to efficiently meet customer needs both now and in the future (Sheikh, 2002). The function of supply chain management is to coordinate the flow of goods, information, and money between all companies related to the supply of goods, manufacturing companies that process the goods supplied, distributor companies, and retail companies (Sharma, 2017).

One of the essential things in supply chain management is sharing information. Therefore material flow, cash flow, and information flow are all elements in the supply chain that need to integrate (Chen, 2019). According to Sanders (2011), the application of supply chain management provides various benefits for a business's supply chain system. Supply chain management is a strategy of obtaining goods from outside and building long-term partnerships to satisfy customers (Wuwung, 2013). Supply chain management aims to assemble a supply chain structure to be more optimal in competitive advantage and provide benefits to end consumers (Assauri, 2011).

One of the models used to measure supply chain performance is the Supply Chain Operations Reference (SCOR) developed by the Supply Chain Council (SCC), which is used as a supply chain management analysis tool. According to Maulidah et al. (2018), the SCOR model can provide a framework for linking processes, metrics, best practices, and technology to facilitate supply chain members' communication. SCOR is a model based on the supply chain process divided into five core processes, including plan, source, make, deliver, and return. Albertin (2017) states that the planning process is a process that aims to balance demand and supply so that the best action is obtained. The source process is procuring goods and services to fulfill demand, which in this process includes scheduling, delivery from suppliers, receiving, checking, and authorizing payments. The making process is a process that processes raw materials so that they add value to the product. Meanwhile, the delivery process is a process to fulfill the demand for goods, including order management, transportation, and distribution. The return process is a product return process for various reasons, such as returning products due to defects, scheduling returns, and making returns (Pujawan, 2009).
The supply chain management concept is expected to integrate various business functions known as the SCOR model, which consists of five core supply chain business processes: Plan, Source, Make, Deliver, and Return. This concept can be applied to the management of a supply chain (Walters, 2006).

However, the supply chain operation in the tobacco products industry of business process in East Java is inseparable from the various risks that can cause losses to the tobacco products industry, so that mitigation measures are needed to overcome possible risks.

Some ways can be used in developing a mitigation strategy, namely by using the SCRM (Supply Chain Risk Management) concept. According to Neiger et al. (2009), SCRM is an approach to planning, controlling, supervising, and implementing various management concepts to ensure the supply process runs with planned provisions. In general, the supply chain risk management process consists of risk identification, risk analysis, risk evaluation, and risk mitigation (Ulfah et al., 2016).

Supply chain risk management is a combination of supply chain management concepts and risk management (Brindley, 2004). According to Zsidisin et al. (2004), supply chain risk management is related to supplier failure to supply goods so that consumer demand is not fulfilled. Meanwhile, according to Peck et al. (2003), supply chain risk management is a risk that occurs in the flow of products, information, raw materials to final product delivery. Supply chain risk can be defined as an event caused by an imbalance between demand and supply.

Risk management can be an alternative in optimizing the expected results from the risk and risk tolerance (Crane et al., 2014). According to Ulfah et al. (2016), it is essential to have risk management in the supply chain in a business or business. Given the complexity in the supply chain, it can increase the likelihood of risk and requires a coping strategy through supply chain risk management.

This research was conducted to analyze the priority level of risk and formulate a risk mitigation strategy for East Java's tobacco supply chain using the SCOR business process model approach. The process of identifying risk events and supply chain risk agents is approached by the SCOR business process model, which consists of five business processes: plan, source, make, deliver, and return. The method of analysis used 
is the Delphy method. Meanwhile, to analyze the risk priority and formulation of risk mitigation strategies using the House of Risk (HoR) Phase 1 and 2 methods.

\section{Research Methods}

This study will examine the tobacco supply chain's mitigation strategies or risk management using the SCOR (Supply Chain Operations Reference) business process model approach. The research location was determined purposively, namely in East Java Province. The reasons for choosing the location were based on various considerations, namely (1) East Java is the primary tobacco-producing area in Indonesia; (2) East Java is designated as the most extensive tobacco products industrial area in Indonesia; and (3) East Java is one of the consumers of tobacco products.

Respondents in this study were the supply chain network of the tobacco products industry in East Java. In the supply chain study, in determining the critical respondent, it is necessary to determine the focal firm or focal company first, while the next respondent will be determined based on the network integration, both backward linkage, and forward linkage. In the tobacco products industry's supply chain network, the group of respondents who become the focal firms are processors (manufacturers), namely the tobacco products industry, where the method of determination is done purposively. The next respondent is determined using the snowball method, both upstream and downstream.

The data analysis methods used included (1) Delphy method; used to identify risk events and sources of risk; (2) House of Risk (HoR) method phase 1; used to analyze risk priorities (risk priority); (3) House of Risk (HoR) phase 2 to formulate a risk mitigation strategy for the supply chain business process.

Delphy is a method for gathering information about potential risks from experts. This method is used to get a collective view of individuals about a problem when there is a situation that shows little or no definite evidence. This method has been widely used in various fields, such as forecasting, priority criteria, and concept development. The Delphy method provides better results than the traditional survey model because it uses brainstorming and in-depth interviews (Widiasih et al., 2015).
Meanwhile, the House of Risk (HoR) is a method that combines two approaches: failure mode and effect analysis (FMEA) and the house of quality (HoQ). HoR is divided into two phases, namely: HoR phase 1 and HoR phase 2 . The Phase HOR method analyzes the weight of risk events (Risk Events) and sources of risk (Risk Agents). Phase $1 \mathrm{HOR}$ is an initial stage that aims to identify risk events and potential risk agents. The role of HoR in the first phase is to rank risk agents based on Aggregate Risk Potential (ARP). The House Of Risk (HOR) method is used to analyze the Supply Chain Risk Mitigation strategy. The role of HoR in the second phase is to prioritize actions or preventive actions that the company must take to maximize effectiveness in its efforts to deal with the risk agents selected in HoR phase 1 (Setiawan, 2018).

\section{Results and Discussion}

The supply chain has a vital role in the success of the tobacco products industry because the supply chain is a concept of a system consisting of various actors involved in the processing and adding value-added from raw materials to final goods used to meet the needs of end consumers. The supply chain consists of all entities that participate in producing and delivering the final product to the end consumer (Sanders, 2011). According to Supriatna et al. (2016), a supply chain structure is said to be successful if an effective and efficient system is created to provide benefits to all actors involved in the supply chain.

\subsection{Identification of Risk Events and Risk Agents}

Identifying risks in the tobacco supply chain system is carried out using field observations and interviews with companies, using questionnaire data, and brainstorming with relevant managers. The mechanism for determining risk identification is carried out based on mapping the SCOR model and the Delphy method, which consists of a business process plan, source, make, deliver, and return.

Based on the use of the Delphy questionnaire, the results of potential risks that may occur in the supply chain system of the Tobacco Products Industry are obtained. There were many as 20 risk events (risk events) and 20 sources of risk (risk agent) in each supply chain business process in the SCOR model where one or more risk agents can cause one risk event. 
There are 20 risk events; related to the planning process (plan) are: delay in production schedules, production targets not achieved, changes in production plans, raw material requirements not achieved; related to the raw material procurement process (source) are: late delivery by farmers, late delivery of supporting materials, high raw material prices, quality of tobacco does not meet standards; related to the production process (make), production stops suddenly, products fail, workers are not honest in their work, worker accidents, workers resign; related to the delivery process (deliver) are: there are transaction costs (extortion), traffic accidents, errors in delivery addresses to significant agents, product damage during delivery; related to the return process are: defective product returns, bankrupt agents, unsold products in the market.

There are 20 sources of risk (risk agents), namely: uncertain economic conditions, tobacco not available in farmers, remote locations of raw materials, prices increase due to excise tax, demand increases sharply, limited skills of workers, government regulations do not support tobacco products industrial companies, prices high due to transaction costs, competition between tobacco product industries, farmers failing to harvest, workers not paying attention to standard operating procedures, lack of marketing planning, lack of worker discipline, unsatisfied harvest schedules, workers dissatisfied with salaries, farmers taking big profits, production machines old, wet tobacco, warehouse stockpiling up, unpredictable natural factors.

\subsection{Risk Priority Level: HOR (House of Risk) Method Phase 1}

After identifying risk events and risk sources, the next step is to assess their severity and occurrence. The purpose of conducting a severity assessment is to determine the impact of a risk event on the company's business process based on how much disruption is caused by a risk event to the company's business processes (Ulfah et al., 2016). To find out a list of risk events in the tobacco supply chain for the tobacco products industry and the results of severity assessment can be seen in Table 1 .

Based on the results of Table 1, it is known that the results of the severity assessment of each risk event that has been assessed by the respondent. Assessment of risk events based on the level of impact arising from these risks. The results show that the Tobacco Products Industry's supply chain system's risk impact is categorized from large to very large.

Table 1. Results of Risk Event Identification and Severity Assessment

\begin{tabular}{|c|c|c|c|c|}
\hline $\begin{array}{c}\text { Major } \\
\text { Processes }\end{array}$ & Sub-Processes & Risk Event & $\begin{array}{l}\text { Severity } \\
(\mathbf{S i})\end{array}$ & Code \\
\hline \multirow{4}{*}{ Plan } & \multirow{3}{*}{ Production Planning } & Production schedule delays & 4 & E1 \\
\hline & & The production target was not reached & 4 & E2 \\
\hline & & Production plan changes & 5 & E3 \\
\hline & $\begin{array}{l}\text { Preparation of the required } \\
\text { amount of tobacco material }\end{array}$ & The need for raw materials is not achieved & 5 & E4 \\
\hline \multirow{4}{*}{ Source } & \multirow{3}{*}{$\begin{array}{l}\text { Fulfillment of raw material } \\
\text { needs }\end{array}$} & Delay in sending farmers & 4 & E5 \\
\hline & & Late delivery of supporting materials & 5 & E6 \\
\hline & & High raw material prices & 4 & E7 \\
\hline & Tobacco quality control & $\begin{array}{l}\text { Tobacco quality does not meet standards } \\
\text { Production stopped suddenly }\end{array}$ & 4 & E8 \\
\hline \multirow{5}{*}{ Make } & \multirow{5}{*}{ Production process } & Product failed & 5 & E9 \\
\hline & & Workers are not honest in their work & 4 & E10 \\
\hline & & Worker's accident & 4 & E11 \\
\hline & & Worker resigns & 5 & E12 \\
\hline & & There is a transaction cost (extortion) & 4 & E13 \\
\hline \multirow{4}{*}{ Deliver } & \multirow{4}{*}{ Product delivery } & Traffic accident & 5 & E14 \\
\hline & & Delivery address error & 4 & E15 \\
\hline & & Product damage during delivery & 5 & E16 \\
\hline & & Returns due to defective products & 5 & E17 \\
\hline \multirow{3}{*}{ Return } & \multirow{3}{*}{$\begin{array}{l}\text { Return of products by } \\
\text { major agents }\end{array}$} & The agent is broke & 4 & E18 \\
\hline & & Products do not sell in the market & 5 & E19 \\
\hline & & Production schedule delays & 5 & E20 \\
\hline
\end{tabular}


Meanwhile, the purpose of conducting an occurrence assessment is to determine the level of opportunity for the risk agent that has the potential to disrupt business processes. To see a list of risk agents and the results of the occurrence assessment can be seen in Table 2 .

Meanwhile, the results of Table 2 show the results of the occurrence of the 20 risk agents assessed by the respondents. The assessment of the frequency of risk sources in the Tobacco Products Industry is included in the category of possible, likely, and almost unavoidable.

Table 2. List of Risk Agents and Occurrence Assessment Results

\begin{tabular}{|c|c|c|}
\hline Risk Agent & Occurrence & Code \\
\hline $\begin{array}{l}\text { The economic situation is } \\
\text { uncertain }\end{array}$ & 3 & A1 \\
\hline $\begin{array}{l}\text { There is intense } \\
\text { competition between the } \\
\text { tobacco products industry }\end{array}$ & 3 & $\mathrm{~A} 2$ \\
\hline Farmers failed to harvest & 5 & A3 \\
\hline $\begin{array}{l}\text { Demand has increased } \\
\text { sharply }\end{array}$ & 4 & A4 \\
\hline $\begin{array}{l}\text { Harvest schedule is not on } \\
\text { time }\end{array}$ & 4 & A5 \\
\hline $\begin{array}{l}\text { Tobacco is not available at } \\
\text { the farm level }\end{array}$ & 4 & A6 \\
\hline $\begin{array}{l}\text { The location of raw } \\
\text { materials is far from } \\
\text { production activities }\end{array}$ & 5 & A7 \\
\hline $\begin{array}{l}\text { Prices increase due to } \\
\text { excise tax }\end{array}$ & 5 & A8 \\
\hline $\begin{array}{l}\text { High prices due to } \\
\text { transaction fees }\end{array}$ & 3 & A9 \\
\hline $\begin{array}{l}\text { Government regulations do } \\
\text { not support the tobacco } \\
\text { products industry }\end{array}$ & 5 & A10 \\
\hline Wet tobacco & 3 & A11 \\
\hline $\begin{array}{l}\text { Workers do not pay } \\
\text { attention to standard } \\
\text { operating procedures }\end{array}$ & 3 & A12 \\
\hline Limited skills of workers & 5 & A13 \\
\hline $\begin{array}{l}\text { Workers are not satisfied } \\
\text { with reward (salary) }\end{array}$ & 3 & A14 \\
\hline Less discipline of workers & 3 & A15 \\
\hline $\begin{array}{l}\text { The production machine is } \\
\text { old }\end{array}$ & 4 & A16 \\
\hline Lack of marketing planning & 3 & A17 \\
\hline Farmers make big profits & 3 & A18 \\
\hline $\begin{array}{l}\text { Unpredictable natural } \\
\text { factors }\end{array}$ & 4 & A19 \\
\hline $\begin{array}{l}\text { Warehouse stock is piling } \\
\text { up }\end{array}$ & 5 & $\mathrm{~A} 20$ \\
\hline
\end{tabular}

After assessing severity and occurrence, the next step is to evaluate the correlation between risk events and risk agents. The scale used to determine correlation is $0,1,3$, or 9 . The number 0 shows no correlation at all. Figures 1 , 3,9 show the consecutive correlation of low, medium, and high. If a risk agent causes a risk event, it can be said that there is a correlation. The higher the correlation value shows a strong correlation between the risk event and the risk agent. After getting the correlation value between the risk event and the risk agent, the next step is calculating the Aggregate Risk Potential (ARP). To find out the ARP value, use the severity, occurrence, and correlation assessment results. The ARP calculation can be calculated through the following formula:

$$
A R P_{j}=O_{j} \sum S_{i} R_{i j}
$$

Where $O_{j}$ is the occurrence risk agent value, $S_{i}$ is the risk event severity value, $R_{i j}$ is the correlation value between the risk event $i$ and the $j$ risk agent, $i$ is the 1 st, 2 nd, 3 rd risk event, etc., and $j$ is the risk source to $1 \mathrm{st}, 2 \mathrm{nd}, 3 \mathrm{rd}$, etc.

After the ARP value is obtained from the Phase 1 HOR calculation results, the next step is to sort the risk agent by using the Pareto diagram approach in Figure 1.

The Pareto diagram is designed by sorting the ARP value from the largest to the smallest, which can be seen in Figure 1, so that in this figure it can be seen that the results of the analysis of the phase 1 HOR method with ARP calculations and the Pareto diagram show the most significant ARP value that needs to be sought for preventive action, namely (A1) the economic situation is uncertain, (A6) tobacco is not available at the farm level, (A7) the location of raw materials is far from production activities, (A8) product prices have risen due to excise duties and (A4) product demand has increased sharply.

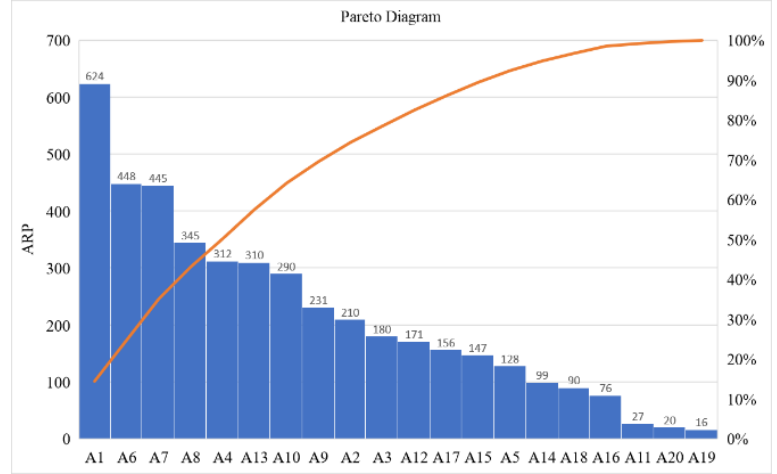

Figure 1. Pareto Aggregate Risk Potential (ARP) diagram 


\subsection{Supply Chain Risk Mitigation Strategy: HOR (House of Risk) Method Phase 2}

To be able to develop a risk mitigation strategy that occurs in the supply chain system, it can be done with the House of Risk (HOR) phase 2.Based on Octavia et al. (2019), implementation of phase $2 \mathrm{HOR}$ is carried out to prioritize risk management actions by looking at the effectiveness of these actions. In the HOR phase 2 , several of the most effective treatment strategies will be selected to reduce the probability of the risk source's impact.

Referring to the results of the phase $1 \mathrm{HOR}$ and the Pareto diagram results, it is found that five potential sources of risk have the most considerable ARP value, so they are used as risk priorities to find appropriate mitigation actions (preventive action). The five potentials are (A1) the economic situation is uncertain, (A6) tobacco is not available at the farmer level, (A7) the location of raw materials is far from production activities, (A8) product prices rise due to excise duties and (A4) product demand is increasing sharply.

The purpose of determining preventive action is to reduce potential, move, and accept risk events. To be able to determine preventive action, obtained from the results of the Delphi questionnaire from respondents.

After determining the preventive action, the next step is to assess the degree of difficulty (Dk) in implementing preventive action. The purpose of the Dk assessment is to determine the level of difficulty in implementing mitigation strategies. The Dk rating scale uses numbers from 1-5. The number 1 means very easy, and number 5 means very difficult. The results of the Dk assessment can be seen in Table 3 .

After it is known that there are 20 risk agents and 16 preventive actions, then the correlation between preventive action and the risk agent is compared. Determination of correlation is needed to determine the level of effectiveness of a mitigation measure to solve the causes of risk. Determining the correlation level can be done by creating a correlation matrix between risk agents and preventive action.

According to Octavia et al. (2019), risk prevention measures must be well determined and can prevent several sources of risk by comparing the relationship between risk agents and preventive action using a scale of $0,1,3$, and 9. The scale used to determine correlation is 0,1 , 3 , or 9 . The number 0 indicates no correlation at all. Figures 1, 3, 9 show the consecutive correlation of low, medium, and high.

Table 3. Results of Assessment of Degree of Difficulty from Preventive Action

\begin{tabular}{|c|c|c|}
\hline Code & Preventive Action & $\begin{array}{l}\text { Degree } \\
\text { of } \\
\text { Difficulty } \\
\text { (Dk) }\end{array}$ \\
\hline PA1 & $\begin{array}{l}\text { The supply of tobacco raw } \\
\text { materials is increased }\end{array}$ & 3 \\
\hline PA2 & $\begin{array}{l}\text { Enforcement of information } \\
\text { systems and technology in } \\
\text { calculating the number of } \\
\text { tobacco products or processed } \\
\text { products }\end{array}$ & 3 \\
\hline PA3 & $\begin{array}{l}\text { Secure tobacco stocks in } \\
\text { warehouses }\end{array}$ & 1 \\
\hline PA4 & Set the highest price & 4 \\
\hline PA5 & $\begin{array}{l}\text { Tightening standard operating } \\
\text { procedures }\end{array}$ & 3 \\
\hline PA6 & $\begin{array}{l}\text { Reducing the supply of } \\
\text { tobacco raw materials (Just in } \\
\text { Time) }\end{array}$ & 1 \\
\hline PA7 & Evaluating agent selection & 2 \\
\hline PA8 & $\begin{array}{l}\text { Improved coordination with } \\
\text { government }\end{array}$ & 2 \\
\hline PA9 & $\begin{array}{l}\text { Increase the flow of } \\
\text { information between agents } \\
\text { and the tobacco products } \\
\text { industry }\end{array}$ & 1 \\
\hline PA10 & $\begin{array}{l}\text { Forge partnerships with } \\
\text { tobacco farmers }\end{array}$ & 1 \\
\hline PA11 & $\begin{array}{l}\text { Keep buying raw materials for } \\
\text { production inventory }\end{array}$ & 1 \\
\hline PA12 & $\begin{array}{l}\text { The stock provision in the } \\
\text { warehouse }\end{array}$ & 3 \\
\hline PA13 & $\begin{array}{l}\text { Improve promotion and } \\
\text { quality }\end{array}$ & 2 \\
\hline PA14 & Increase production capacity & 3 \\
\hline PA15 & $\begin{array}{l}\text { Replacement of production } \\
\text { support materials }\end{array}$ & 5 \\
\hline PA16 & Maintain product quality & 2 \\
\hline
\end{tabular}

The correlation assessment matrix results between preventive action and risk agent show a correlation between preventive action (PA) and risk agent (Ai). After knowing the correlation, the next step is to calculate the total effectiveness of 
action (Tek) for each preventive action. The purpose of calculating the Tek is to assess each application of preventive action's effectiveness. The following is a calculation formula and an example for solving Tek calculations:

$$
T E_{k}=\sum_{j} A R P_{j} . E_{j k}
$$

Where $T E_{k}$ is the level of difficulty, $A R P_{j}$ is the aggregate risk potential of risk agent $j$, and $E_{j k}$ is the correlation relationship between risk agent $j$ and preventive action $k$. Here is the $\mathrm{TE}_{\mathrm{k}}$ on PA1:

$$
\mathrm{TEk}_{1}=(9 \times 624)+(3 \times 312)=6552
$$

The calculation result of 6552 shows the level of effectiveness of preventive action in reducing the risk agent's impact. These results are obtained from the calculation between the preventive action correlation value with the risk agent and the Aggregate Risk Potential value in each risk agent.

After getting the TEk value, the next step is to calculate the Effectiveness of Difficulty (ETDk). ETDk calculation is to determine preventive action priorities. The ETDk value results will make it easier for companies to carry out preventive action measures by risk agents (Magdalena and Vannie, 2019). After the ETDk value is obtained, a preventive action selection will be carried out based on the level of effectiveness of mitigation measures to resolve problems related to risk events caused by risk agents. The selected mitigation action results from the largest ETDk value ranking so that the preventive action will be chosen to be implemented. The following is a calculation formula and an example of settling ETDk calculations:

$$
E T D_{k}=\frac{T E_{k}}{D_{k}}
$$

Where $E T D_{k}$ is the effectiveness to difficulty ratio, and $D_{k}$ is the degree of difficulty performing the action. Here is the ETDk PA1 calculation:

$$
\mathrm{ETDk}_{1}=\frac{6552}{3}=2184
$$

The value of 2184 is the value of effectiveness to difficulty, which means showing the level of effectiveness of preventive action by considering its ability to be applied to the company. The higher the ETDk value, the preventive action becomes a priority to be implemented. The ETDk results show the priority of preventive action to be implemented.
The following is a sequence of supply chain risk mitigation strategies with a business process model compiled for the Tobacco Products Industry's supply chain.

1. Increasing the flow of information between agents (distributors) and the Tobacco Products Industry (PA9) has an ETDk value of 11529, making it the first priority mitigation strategy in the Tobacco Products Manufacturing supply chain system. This strategy can be used to overcome risk agents caused by economic aspects. This mitigation strategy can reduce the impact of the occurrence of uncertain economic conditions (A1), the price of processed tobacco products increases due to excise taxes (A8), and the demand for processed tobacco products increases sharply (A4). The existence of a robust and open exchange of information between the Tobacco Product Manufacturers and large agents will provide efficiency in the supply chain system. According to Lotfi (2013), information sharing in the supply chain can provide benefits for companies because they can plan products according to consumer demand and cope with market changes. Information sharing between the Tobacco Products Industry Manufacturers and primary agents has a vital role in the supply chain's success. This strategy has a value of 1 in degrees of difficulty, which means that this strategy is straightforward to implement.

2. Reducing the demand for tobacco raw material supply / Just In Time (PA6) has an ETDk value of 5616. This strategy can be used to overcome the risk of uncertain economic conditions (A1) (Sharma, 2017). Implementing this mitigation strategy aims to avoid losses in tobacco leaf storage and streamline the production of processed tobacco products. The criterion for success in reducing supply is that none of the raw materials used in producing processed tobacco products is wasted. The implementation of this strategy has a value of 1 in degrees of difficulty, which means that this strategy is straightforward to implement.

3. Securing tobacco stocks in warehouses (PA3) has an ETDk value of 5487. This strategy can be used to prevent risks in the form of uncertain economic conditions (A1), tobacco not available at the farmer level (A6), and the location of raw materials far from production activities (A7). The supply of tobacco used by 
the Tobacco Products Industry Manufacturers comes from outside of East Java, thus requiring the Tobacco Products Industry Manufacturers to secure tobacco stocks in warehouses to carry out tobacco processing production activities. According to Sohail (2018), the benefits of securing raw material stocks are to anticipate market changes and maintain company operations. This strategy has a value of 1 in degrees of difficulty, which means this strategy is straightforward to implement.

4. Evaluating agent selection (PA7) has an ETDk value of 3326. Based on the experience of the Tobacco Products Manufacturing Industry, which faces a problem in the form of large agents unable to pay bills for processed tobacco, causing substantial financial losses on the part of the Tobacco Products Industry Manufacturing The cause of the problem of large agents who are unable to pay for products is due to uncertain economic conditions (A1) and an increase in excise prices for processed tobacco (A8). As for choosing a large agent, it can be evaluated through its financial performance, operational area, and the stipulated selling price of processed tobacco products. According to Abidi et al. (2019) and Maulidah et al. (2016), determining the right business partner can be through financial criteria, organizational criteria, operational criteria, and strategic criteria. The choice of strategy is easy to implement because it has a value of 2 on the degree of difficulty.

5. Forging partnerships with tobacco farmers (PA10) has an ETDk value of 2679. This strategy can overcome sources of risk in the form of tobacco not available at the farmer level (A6) and the location of raw materials far from production activities (A7) (Muchfirodin et al., 2014; Maulidah, 2012). This strategy has a value of 1 in the degree of difficulty, which means it is straightforward to implement.

6. The supply of tobacco raw material stocks in warehouses (PA12) has an ETDk value of 2679. This strategy can overcome the source of risk in the form of raw materials not available at the farm level (A6) and the location of raw materials far from production activities (A7) (Indriani et al., 2020). Therefore, the Tobacco Product Manufacturing Industry needs to provide a stock of raw materials and supporting materials to produce processed tobacco products so that the planned operational activities can be carried out. The implementation of this strategy has a value of 3 on the degree of difficulty, which means that it is neutral to apply.

7. Supply of raw materials is increased (PA1), has an ETDk value of 2184. This strategy can overcome risks in uncertain economic conditions (A1) and increased the demand for processed tobacco products (A4). This strategy can be applied to meet high consumer demand, so it is necessary to increase production. Increased production requires an increase in raw materials and supporting materials (Mulligan, 2019). Implementing this strategy can be neutral because it has a value of 3 on the degree of difficulty.

8. Increasing promotion and quality (PA13) has an ETDk value of 1454. This strategy can overcome the risk of uncertain economic conditions (A1) and the price of processed tobacco products rising due to excise tax (A8). This mitigation strategy can be applied by the Tobacco Product Manufacturing Industry so that sales of processed tobacco products continue to run smoothly and increase consumers' number. The importance of improving product quality and promotion is included in the opinion of Bakator and Petrovic (2016) that product quality shows business performance and the advantages of the company, while the increase in production activities shows the effectiveness of the company in attracting consumers to buy the products and services offered (Magdalena et al., 2019). As for implementing this strategy, it can be said that it is easy because it has a value of 2 on the degree of difficulty.

9. Increase production capacity (PA14), with an ETDk value of 936, namely increasing production capacity. The selection of this mitigation strategy can be applied to anticipate a source of risk in the form of a sharp increase in demand for processed tobacco products (A4) (Su et al., 2012). Through the implementation of this strategy, IHT Manufacturers can meet consumer demand for processed tobacco products produced. Implementing this mitigation strategy can be said to be neutral because it has a value of 3 on the degree of difficulty. 
10. Setting the highest tobacco raw material price (PA4), with an ETDk value of 670. The implementation of this strategy aims to prevent problems related to the availability of tobacco raw materials on partner farmers (A6) (Amir et al., 2014). Giving the highest price will make it easier for Tobacco Products Industry Manufacturers to continue to obtain tobacco raw materials through other tobacco farmers with tobacco quality following company standards so that production activities can still be carried out. This mitigation strategy can be challenging to implement because it has a value of 4 on the degree of difficulty.

11.Maintaining product quality (PA16), with an ETDk value of 518. This strategy was chosen based on the company's ability to improve quality control on the processed tobacco products produced so that the quality produced would remain the same. Quality control is carried out to prevent product returns and complaints from consumers regarding processed tobacco products produced by the Tobacco Products Industry Manufacturers. Maintaining product quality by conducting quality control plays a vital role in maintaining consumer confidence in processed tobacco products. Supported by Sawitri (2016) statement, product quality affects consumer satisfaction from purchasing a product to form consumer loyalty to the product offered (Anggraeni et al., 2016). This mitigation strategy can be easy to implement because it has a value of 2 on the degree of difficulty.

12.Improved coordination with the government (PA8) has an ETDk value of 485. Companies can coordinate with the government to exchange information through economic conditions that can affect business activities' stability (Cahyani et al., 2016). Implementing this strategy can prevent an increase in excise on processed tobacco that is too sudden and too high, which results in higher prices for processed tobacco products (A8). Implementing this mitigation strategy is said to be easy because it has a value of 2 on the degree of difficulty.

13. Keep buying raw materials for production supplies (PA11), with an ETDk value of 448. The company can implement this mitigation strategy by purchasing tobacco raw materials from partner farmers. This strategy is implemented to prevent obstruction of production activities due to the unavailability of primary raw materials caused by farmers failing to harvest (A3), wet tobacco (A11), unavailability of processed tobacco on the part of farmers (A6), locations of raw materials far from production activities (A7), as well as the increasing demand for processed tobacco products (A4). The availability of raw materials can make it easier for companies to carry out production activities to meet the demand for consumer tobacco processed products. Supported by Ishak's (2010) statement that the availability of raw materials is intended to meet high production demand so that sufficient raw materials are needed so that the production process is not disrupted due to unavailable raw materials. Also, the supply of raw materials is an essential requirement for companies to support the implementation of the production process to meet consumer demand (Rahman, 2018). This mitigation strategy can be straightforward to implement because it has a value of 1 in the degree of difficulty.

14. The application of information systems and technology in calculating the number of processed tobacco products produced (PA2), with an ETDk value of 312, namely the application of information systems and technology in calculating the number of processed tobacco products produced. Companies can implement this mitigation strategy to make it easier to control the stocks of processed tobacco products produced and the stocks in warehouses. The calculation of the amount of processed tobacco produced aims to facilitate the planning of the amount of production and marketing to be carried out by the company through information systems and technology. The importance of implementing information systems and technology strategies to facilitate companies is supported by Aziz (2012) statement that information technology in a company can work as automation so that work will be more efficient and effective. Also, applying information technology can make it easier for companies to make decisions quickly and accurately to achieve business processes' objectives (Sawitri, 2016). Implementing this mitigation strategy is said to be neutral because it has a value of 3 on the degree of difficulty. 
15.Tightening standard operating procedures (PA5), having an ETDk value of 148. The selection of PA5 mitigation strategies aims to maintain the quality of processed tobacco products and know the worker performance in the company. Implementing this proposed mitigation strategy is to avoid a decrease in the quality of processed tobacco products and damage to processed tobacco products and packaging of processed tobacco products during production activities due to workers who ignore standard operating procedures (A12) and limited skills of workers (A13). Also, tightening standard operating procedures can improve worker discipline to improve worker performance to support production activities. It is strengthened by Santosa's (2014) opinion that standard operating procedures are aimed at practically regulating activities, disciplining members in the company, making it easier to increase workers' knowledge and experience so that they can anticipate mistakes. This mitigation strategy is said to be neutral because it has a value of 3 on the degree of difficulty.

16. Replacement of production supporting raw materials (PA15) with ETDk value of 90. This mitigation strategy was chosen to meet the product quality desired by the company (Octavia et al., 2019). Implementing this mitigation strategy aims to make it easier for companies to recompile the composition of the tobacco processed ingredients that will be produced if one of the supporting materials is not available. Implementing this mitigation strategy is very difficult to implement because it has a value of 5 on the degree of difficulty.

\section{Conclusion}

The risk priority level of the tobacco supply chain risk agents using the SCOR Model (Supply Chain Operations Reference) approach is: (A1) uncertain economic conditions, (A6) tobacco not available at the farmer level, (A7) the location of raw materials is far from production activities, (A8) product prices rise due to customs duties and (A4) product demand increases sharply.

The tobacco supply chain risk mitigation strategy using the SCOR Model (Supply Chain Operations Reference) or Preventive Action Model is:

a. Improve the flow of information in the tobacco supply chain network (PA9) b. Perform stock management/inventory of tobacco raw materials and processed tobacco products (PA6; PA3; PA12; PA1; PA14; PA11; PA5; PA15)

c. Evaluating customer selection (PA7)

d. Establish partnerships with tobacco farmers (PA10)

e. Perform a marketing mix strategy (Product, Price, Place, Promotion) (PA13; PA4; PA16)

f. Improved coordination with the government (PA8)

g. Management of information systems and technology (PA2)

\section{References}

Abidi, H., Dullaert, W., De Leeuw, S., Lysko, D., \& Klumpp, M. (2019). Strategic partner evaluation criteria for logistics service provider networks. The International Journal of Logistics Management.

Albertin, Yan Coelho. 2017. Supply Chain Risk Management: Understanding and Facing the Main risks on the Chain. Bachelor's thesis Logistic Engineering. South-Eastern Finland. University of Applied Sciences.

Amir, N.O., Syafrial., \& Koestiono, D. (2014). Analisis Manajemen Rantai Pasokan (Supply Chain Management) Komoditas Pisang Mas Kirana (Kasus pada Asosiasi Petani Pisang Mas Sridonoretno, Kec. Dampit, Kab. Malang. Habitat, 25(1): 4960.

Anggraeni, D.P., Kumadji, S., \& Sunarti. (2016). Pengaruh Kualitas Produk terhadap Kepuasan dan Loyalitas Pelanggan (Survei pada Pelanggan Nasi Rawon di Rumah Makan Sakinah Kota Pasuruan). Jurnal Administrasi Bisnis, 37(1): 171-177.

Assauri, S. (2011). Manajemen Produksi dan Operasi. Jakarta: Lembaga Penerbit FEUI.

Aziz, A. (2012). Pemanfaatan Teknologi Informasi dalam Pengembangan Bisnis Pos. Buletin Pos dan Telekomunikasi, 10(1): 35-50.

Bakator, M., \& Petrović, N. (2016). Correlation between marketing strategy, product quality and promotion on the mobile devices market in Serbia. Journal of Engineering Management and Competitiveness (JEMC), 6(2), 67-74. 
Brindley Claire. (2004). Supply Chain Risk. Hampshire Ashgate.

Cahyani, Z.D., Pribadi, S.R.W., \& Baihaqi, I. (2016). Studi Implementasi Model House of Risk (HOR) untuk Mitigasi Risiko Keterlambatan Material dan Komponen Impor pada Pembangunan Kapal Baru. Jurnal Teknik ITS, 5(2): 52-29.

Chen, C. J. (2019). Developing a model for supply chain agility and innovativeness to enhance firms' competitive advantage. Management Decision.

Crane, L., Gantz, G., Isaacs, S., Jose, D., \& Sharp, R. (2014). Introduction Risk Management. United States Department of Agriculture: Extension Risk Management Education and Risk Management Agency.

Indriani, R., Darma, R., Musa, Y., Tenriawaru, A.N., \& Imran, S. (2020). Product Flow Pattern at Cayyene Pepper Supply Chain. Earth and Environmental Science 486, 1-8.

Ishak, Aulia. (2010). Manajemen Operasi. Yogyakarta: Graha Ilmu.

Lotfi, Z. (2013). Information Sharing in Supply Chain Management. Elsevier Procedia Technology, 11: 298-304.

Magdalena, R., \& Vannie. (2019). Analisis Risiko Supply Chain dengan Model House of Risk (HOR) pada PT. Tatalogam Lestari. Jurnal Teknik Industri, 14(2): 53-62.

Maulidah, Silvana, Djoko Koestiono, Soemarno, A Wahib Muhaimin. 2018. Supply Chain Integration of Potato Agro-Industry: Primary Management Processes Perspective. Scholars Journal of Economics, Business and Management (SJEBM). http://saspjournals.com/wpcontent/uploads/ 2018/09/SJEBM-58-745754-c.pdf

Maulidah, Silvana, \& Fitri Megayanti. 2016. Analisis Efisiensi Distribusi pada Penjualan Produk Olahan Buah dan Sayuran dengan Metode Data Envelopment Analysis (DEA). Jurnal Agriekonomika Volume 5 Nomor 2. https://doi.org/10.21107/agriekonomika .v5i2.1594

Maulidah, Silvana. 2012. Pengantar Manajemen Agribisnis. UB Press. Universitas Brawijaya. Malang.
Muchfirodin, Muchammad, Adi Djoko Guritno, Henry Yuliando. 2014. Supply Chain Risk Management on Tobacco Commodity in Temanggung, Central Java (Case study at Farmers and Middlemen Level). Proceeding. The 2014 International Conference on Agro-industry (ICoA) : Competitive and sustainable Agroindustry for

Human

Welfare.https://www.researchgate.net/publ ication/273005987.

Mulligan, Jan. 2019. Supply Chain Risk Management.https://www.acq.osd.mil/log/ MR/.PSM_workshop.html/2019_Files/Day _Two/3_Supply_Chain_Risk_Management _Mulligan.pdf.

Neiger, D., Rotaru, K., Churilov, L. (2009), Supply chain risk identification with valuefocused process engineering, Journal of Operations Management, Vol. 27, 154-68.

Octavia, C.W., Magdalena, R., \& Prasetya, W. (2019). Implementasi House of Risk dalam Strategi Mitigasi Sumber risiko pada Aktivitas di Bagian Produksi PT. XYZ. Jurnal Metris, (20): 58-70.

Peck, H., Christopher, M., \& Kingdom, U. (2003), "Supply Chain Risk Management: Outlining an Agenda for Future Research", International Journal of Logistics: Research \& Applications, 6(4): 197-210.

Pujawan, I. N. (2009). Supply chain house of risk: a model risk management for proactive supply chain. Business Process Management Journal, 15(6), 53-67.

Rahman, A. (2018). Penentuan Jumlah Pembelian Bahan Baku berdasarkan Metode Economic Order Quantity pada PT. Daya Sakti Industri Makasar. Jurnal Sentralisasi, 7(2): 57-72.

Sanders, N. R. (2011). Supply chain management: A global perspective. Wiley Global Education.

Santosa, Joko D. (2014). Lebih Memahami SOP (Standard Operation Procedure). Surabaya: Kata Pena.

Sawitri. (2016). Pengaruh Teknologi Informasi, Pemanfaatan Teknologi Informasi, Efektivitas Penggunaan dan Kepercayaan Teknologi Informasi terhadap Kinerja 
Individual. Publikasi Ilmiah. Universitas Muhammadiyah Surakarta.

Setiawan, Andrika Gummenia. 2018. Analisis Manajemen rantai Pasok Produk Gula Kelapa Kristal. Tugas Akhir. Universitas Islam Indonesia.

Sharma, Jayanta Kar. (2017). Managing Flows and Networks. Sambalpur, Odisha State Open University.

Sheikh, K. (2002). Manufacturing Resource Planning (MRP II). McGraw-Hill.

Sohail, N. 2018. A Study of Inventory Management System Case Study. Journal of Adv Research in Dynamical \& Control System, 10 (10): 1176-1190.

Supriatna, D. C., Perdana, T., \& Noor, T. I. (2016). Struktur Rantai Pasok pada Klaster Sayuran untuk Tujuan Pasar Terstruktur. Agrikultura, 27(2).

Ulfah, M., Maarif, M.S., \& Sukardi, S.R. (2016). Analisis dan Perbaikan Manejemen Risiko Rantai Pasok Gula Rafinasi dengan Pendekatan House of Risk. Journal of Agroindustrial Technology, 26(1).

United States Departement of Agriculture. 2018. Tobacco Loss Adjustment Standards Handbook. https://legacy.rma.usda.gov / hand books/25000/2018/18_25025.pdf.

Walters, D. (2006). Supply Chain Risk Management. London and Philadelphia Kogan Page Limited.

Widiasih, W., Karningsih, P. D., \& Ciptomulyono, U. (2015). Development of Integrated Model for Managing Risk in Lean Manufacturing Implementation: A Case Study in an Indonesian Manufacturing Company. Procedia Manufacturing, 4, 282-290.

Wuwung, S. C. (2013). Manajemen Rantai Pasokan Produk Cengkeh Pada Desa Wawona Minahasa Selatan. Jurnal EMBA: Jurnal Riset Ekonomi, Manajemen, Bisnis dan Akuntansi, 1(3).

Zsidisin, G. A., Ellram, L. M., Carter, J. R., \& Cavinato, J. L. (2004). An analysis of supply risk assessment techniques. International Journal of Physical Distribution \& Logistics Management. 